\title{
Residual effects of potassium placement for conservation-till corn on subsequent no-till soybean
}

\author{
Xinhua Yin, Tony J. Vyn* \\ Department of Agronomy, Purdue University, West Lafayette, IN 47907-1150, USA
}

Received 18 June 2002; received in revised form 7 May 2003; accepted 10 July 2003

\begin{abstract}
Biannual surface application of potassium (K) fertilizer prior to corn (Zea mays L.) in a corn-soybean (Glycine max (L.) Merr.) rotation has been common in conventional-till crop production in North America; however, whether this traditional $\mathrm{K}$ management practice is effective for soybean when both corn and soybean are grown with conservation tillage is largely unknown. This study evaluated the residual effects of spring $\mathrm{K}$ fertilizer placement in conservation tillage systems applied to previous corn on subsequent no-till soybean. Experiments involving a corn-soybean rotation were conducted from 1997 to 2000 on a silt loam soil (Albic Luvisol) with 12 years of continuous no-till management near Paris, Ontario, Canada. The fields had low initial soil-test K levels $\left(<61 \mathrm{mg} \mathrm{l}^{-1}\right)$ and evident soil K stratification in the top $20 \mathrm{~cm}$. In the "corn" years from 1997 through 1999, spring K fertilizer placement methods of deep band ( $76 \mathrm{~cm}$ centers), surface broadcast, broadcast plus shallow band, and no K were evaluated for no-till, spring zone-till, and spring mulch-till tillage systems (1997 and 1998) but for no-till alone in 1999. From 1998 to 2000, soybean was no-till planted in $19 \mathrm{~cm}$ row widths on the respective previous-year corn treatments without further K fertilizer application. Soybean leaf K concentrations responded more frequently and positively to $\mathrm{K}$ application in no-till corn than in zone-till and mulch-till corn. Deep band and surface broadcast $\mathrm{K}$ placements were similar in their residual effects on soybean leaf K. Positive soybean yield responses to residual $\mathrm{K}$ fertilizer were observed in only 1 out of 3 years despite consistent increases in both soil $\mathrm{K}$ and soybean leaf $\mathrm{K}$ concentrations where $\mathrm{K}$ was applied to previous corn. On long-term no-till fields with low soil K levels, interrupting a continuous no-till corn-soybean system with mulch-till corn production provided residual benefits in soil $\mathrm{K}$ availability and leaf $\mathrm{K}$ nutrition for subsequent no-till soybean. Furthermore, the residual effects of $\mathrm{K}$ fertilizer applied to previous corn on subsequent no-till soybean were not affected by K placement method.

(c) 2003 Published by Elsevier B.V.
\end{abstract}

Keywords: Potassium; Soybean; Glycine max (L.) Merr.; No-till; Zone-till; Mulch-till; Residual fertility

\section{Introduction}

Long-term no-till management has resulted in pronounced vertical stratification of soil-test K (Sprague and Triplett, 1986; Karathanasis and Wells, 1989;

\footnotetext{
* Corresponding author. Tel.: +1-765-496-3757; fax: +1-765-496-2926.

E-mail address: tvyn@purdue.edu (T.J. Vyn).
}

Chan et al., 1992; Holanda et al., 1998; Yin and Vyn, 2002a). This K stratification is characterized by significantly higher soil $\mathrm{K}$ concentrations in the surface $0-5 \mathrm{~cm}$ layer and lower $\mathrm{K}$ levels at the $10-20 \mathrm{~cm}$ depth (Holanda et al., 1998). In contrast, soil K distribution within the plow layer is relatively uniform in fields with the conventional tillage (moldboard plow) (Fink and Wesley, 1974; Cruse et al., 1983). Vertical soil $\mathrm{K}$ stratification in no-till fields is mainly attributed to 
limited soil mixing, surface application of $\mathrm{K}$ fertilizer, deposit of crop residue at the soil surface, and the relative immobility of $\mathrm{K}$ in the soil.

The impacts of vertical soil $\mathrm{K}$ stratification on $\mathrm{K}$ nutrition and yield of conservation-till soybean has not been well documented. Theoretically, vertical stratification of soil $\mathrm{K}$ in no-till fields causes plant $\mathrm{K}$ uptake to be more dependent on soil $\mathrm{K}$ and root system characteristics in the surface layer. This may reduce plant $\mathrm{K}$ uptake, and thus increase the likelihood of $\mathrm{K}$ deficiency in crop tissues as well as yield loss in growing seasons when drought occurs, since soil $\mathrm{K}$ availability and root growth and activity in the surface layer are more vulnerable to drought stress than those in sub-surface layers. In addition, crop residue deposit at the soil surface in no-till fields usually results in higher soil moisture and lower soil temperature in the surface layer, which may slow soil $\mathrm{K}$ movement to roots, and restrict root growth and activity early in the season (Barber, 1971; Fortin, 1993). It is speculated that the risks of reduction in plant $\mathrm{K}$ uptake by drought or low temperature in no-till fields may become severe when soil $\mathrm{K}$ concentrations in sub-surface layers are too low to optimize plant $\mathrm{K}$ uptake. Sub-surface placement of K fertilizer, therefore, may improve applied $\mathrm{K}$ availability and reduce soil $\mathrm{K}$ stratification in no-till management.

With conventional-till soybean production in the common corn-soybean crop rotation in North America, $\mathrm{K}$ fertilizer is often applied biannually to previous corn; the subsequent soybean consequently relies on the residual effects of $\mathrm{K}$ fertilizer. Because the area of no-till soybean in North America has increased markedly since the late 1980s, new questions have been raised concerning the effectiveness of applying the $\mathrm{K}$ management systems which were originally designed for conventional-till soybean to no-till soybean production. Information is limited concerning $\mathrm{K}$ fertility management for soybean on no-till fields. Recent investigations in Iowa (Borges and Mallarino, 2000; Buah et al., 2000) showed that no-till soybean yield response to $\mathrm{K}$ fertilization was rarely significant on optimum- to very high-testing soils. Research in Illinois (Vasilas et al., 1988) also reported that no-till management did not affect $\mathrm{K}$ fertilizer recommendations for soybean compared to a traditional tillage system based on a moldboard plow.
Sub-surface placement of K fertilizer seems most likely to be superior to surface broadcasting for no-till soybean on low-testing soils. Hairston et al. (1990) showed that deep banding ( $15 \mathrm{~cm}$ depth) of $\mathrm{K}$ fertilizer resulted in significantly higher yield of no-till soybean than surface broadcasting on some Mississippi soils with low K levels. Research in Ohio (Hudak et al., 1989) demonstrated that banded $K$ fertilizer placement improved soybean yields with no-till, but not with chisel or moldboard plow systems on medium $\mathrm{K}$ soils. Borges and Mallarino (2000) reported that both deep-banded and planter-banded $\mathrm{K}$ fertilizer in no-till resulted in only slightly higher soybean yield than surface application on optimum- to very high-testing soils, and that positive yield response to banding occurred relatively independent of soil-test $\mathrm{K}$ levels or degree of soil $\mathrm{K}$ stratification within the ranges encountered in their studies.

The corn-soybean rotation is the predominant mode of crop rotation in North America. Biannual application of $\mathrm{K}$ fertilizer before corn at rates presumably high enough to satisfy $\mathrm{K}$ requirements of both corn and the subsequent soybean has been a common $\mathrm{K}$ management practice for conventional-till production in North America. Although biannual application reduces costs, information is limited about the residual effects of $\mathrm{K}$ placement for conservation-till corn on subsequent no-till soybean. Yin and Vyn (2002b) recently reported positive yield responses of no-till soybean to both residual fall $\mathrm{K}$ and residual starter $\mathrm{K}$ fertilizer when corn followed soybean on medium-testing K soils. Earlier research in Minnesota (Rehm, 1995) on a high-testing K soil with K stratification after 6 years in ridge-till showed that the residual $\mathrm{K}$ from a high rate of deep-banded $\mathrm{K}$ fertilizer to previous corn significantly increased soybean yield. However, an investigation in Iowa demonstrated that no-till soybean yield responses to residual effect of starter K applied to previous corn were negligible on high-testing soils with a history of at least 10-year continuous no-till (Buah et al., 2000). The residual effects of $\mathrm{K}$ fertilization to conservation-till corn on subsequent no-till soybean have not been documented on low $\mathrm{K}$ soils following long-term no-till.

Both zone-till and mulch-till are conservation tillage alternatives to no-till that improve seed zone fitness for corn, but retain residue cover for soil and water conservation functions (Vyn and Raimbault, 1992, 
1993; Opoku et al., 1997). In addition, both zone-till and mulch-till systems enable some K placement alternatives relative to surface broadcasting in no-till. Zone-till systems often involve equipment capable of banding $\mathrm{K}$ fertilizer into soil deeper than $10 \mathrm{~cm}$ during tillage. Mulch-till incorporates broadcast-applied $\mathrm{K}$ fertilizer into soil in a manner similar to moldboard plow systems, although not to the same depth as the latter. Corn yield benefits associated with deep banding, relative to surface broadcasting, were not evident for corn in no-till, zone-till, or mulch-till system on low $\mathrm{K}$ soils $\left(<60 \mathrm{mgl}^{-1}\right)$, but mulch-till itself after long-term no-till seemed to improve corn $\mathrm{K}$ uptake relative to continuous no-till (Vyn et al., 2002). The residual effects of banded $\mathrm{K}$ placements, relative to surface broadcasting, for corn in conservation-till systems on subsequent no-till soybean is largely unknown on low K soils.

Traditional $\mathrm{K}$ management systems designed for soybean in a corn-soybean rotation under moldboard plow systems may need to be modified to ensure that soil $\mathrm{K}$ stratification and other changes in soil properties with conservation tillage will not limit $\mathrm{K}$ uptake and yield of no-till soybean. The primary objective of this research was to evaluate the residual effects of $\mathrm{K}$ placement and spring tillage systems for corn on soil $\mathrm{K}$ fertility, leaf $\mathrm{K}$ concentrations, and yield of subsequent no-till soybean on a low $\mathrm{K}$ soil following long-term no-till.

\section{Materials and methods}

A field investigation involving a corn-soybean rotation was conducted near Paris, Brant County, Ontario $\left(43.0^{\circ} \mathrm{N}, 80.5^{\circ} \mathrm{W}\right)$ from 1997 through 2000 . The fields chosen for this study had been in continuous no-till production for 12 years prior to treatment initiation for the corn season. All fields were systematically tile drained. The soil was classified as a Brunisolic Gray Brown Luvisol according to Canadian soil classification (Albic Luvisol based on FAO soil classification). Soil textural and fertility properties before corn are presented in Table 1. In this study, Soil K levels before corn planting at the $0-15 \mathrm{~cm}$ depth were estimated by averaging the $\mathrm{K}$ concentrations at $0-5,5-10$, and $10-20 \mathrm{~cm}$ depth intervals. Ontario soil-test $\mathrm{K}$ interpretations for samples at the $0-15 \mathrm{~cm}$ depth are used.
Table 1

General soil characteristics before corn planting from 1997 to 1999

\begin{tabular}{lcccc}
\hline Characteristic (unit) & $\begin{array}{l}\text { Soil depth } \\
(\mathrm{cm})\end{array}$ & 1997 & 1998 & 1999 \\
\hline Texture & $0-15$ & $\begin{array}{l}\text { Silt } \\
\text { loam }\end{array}$ & $\begin{array}{l}\text { Silt } \\
\text { loam }\end{array}$ & $\begin{array}{l}\text { Silt } \\
\text { loam }\end{array}$ \\
Sand $\left(\mathrm{g} \mathrm{kg}^{-1}\right)$ & $0-15$ & 380 & 372 & 363 \\
Silt $\left(\mathrm{g} \mathrm{kg}^{-1}\right)$ & $0-15$ & 530 & 534 & 530 \\
Clay $\left(\mathrm{g} \mathrm{kg}^{-1}\right)$ & $0-15$ & 90 & 94 & 107 \\
Organic C $\left(\mathrm{g} \mathrm{kg}^{-1}\right)$ & $0-15$ & 18 & 23 & 20 \\
Available Pa $\left(\mathrm{mg} \mathrm{kg}^{-1}\right)$ & $0-15$ & 16 & 13 & 22 \\
Available $\mathrm{Mg}^{\mathrm{b}}\left(\mathrm{mg} \mathrm{kg}^{-1}\right)$ & $0-15$ & 182 & 187 & 193 \\
pH & $0-15$ & 5.8 & 6.4 & 6.6 \\
Available Kc $\left(\mathrm{mg} \mathrm{l}^{-1}\right)$ & $0-5$ & 84 & 66 & 78 \\
& $5-10$ & 52 & 40 & 46 \\
& $10-20$ & 44 & 35 & 38 \\
& $20-30$ & 47 & 36 & 38
\end{tabular}

${ }^{a}$ Sodium bicarbonate extractable phosphorous (Schoneau and Karamanos, 1993).

${ }^{\mathrm{b}}$ Ammonium acetate extractable Mg (Simard, 1993).

${ }^{c}$ Ammonium acetate extractable K (Bates and Richards, 1993).

Boundaries of soil $\mathrm{K}$ in low, medium, high, very high, and excessive categories are $<61,61-120,121-150$, 151-250, and $>250 \mathrm{mg} \mathrm{l}^{-1}$ (mg K per liter of soil) for soybean in Ontario, respectively (OMFARA, 1997).

In order to establish experimental sites to test the residual effects of $\mathrm{K}$ fertilizer applied to the previous-year corn on subsequent no-till soybean from 1998 to 2000, corn tests were conducted each year on different, but adjacent fields, from 1997 to 1999. The 1998 soybean test was planted on the 1997 corn trial, the 1999 soybean experiment was conducted on the 1999 corn test, and the 2000 soybean trial was planted on the 1999 corn experiment.

\subsection{Previous corn season}

For the corn season, the experiment was conducted using a randomized complete block split-plot design with four replicates in 1997 and 1998. Spring tillage systems were randomly assigned to the whole plots, and spring $\mathrm{K}$ placement methods were assigned to the split-plots. The three spring tillage systems used in this study were described as follows-(1) No-till: corn was planted no-till using a no-till planter equipped with one fluted coulter and unit-mounted tined row cleaners. The only soil disturbance was associated with the action of planter-mounted coulters and seed-disk 
openers. (2) Zone-till: spring tillage was accomplished in strips approximately $20 \mathrm{~cm}$ wide and $17 \mathrm{~cm}$ deep using a Trans-Till (Row-Tech Inc., Snover, MI). The Trans-Till loosens soil using an angled shank and two coulters are positioned on either side of the shank to help contain soil within the tilled zone. (3) Mulch-till: spring tillage consisted of two to three passes to a depth of $10 \mathrm{~cm}$ with a field cultivator just prior to corn planting. The following four $\mathrm{K}$ placement methods were evaluated in this study-(1) Deep band: fertilizer was applied in a band $15 \mathrm{~cm}$ deep at $76 \mathrm{~cm}$ centers following the completion of spring tillage, and corn rows were planted directly on the top of $\mathrm{K}$ fertilizer bands. (2) Surface broadcast: all K fertilizer was broadcast applied to the soil surface just prior to spring tillage operations. (3) Broadcast plus shallow band: half of the $\mathrm{K}$ fertilizer was surface broadcast applied, the rest was applied through the planter in a starter band $5 \mathrm{~cm}$ to the side of the row and $5 \mathrm{~cm}$ below corn seeding depth. (4) No K: fertilizer was not applied.

For the 1999 corn season, a randomized complete block design was used with four K placement methods as the treatments. The four K placement methods were the same as those used in 1997 and 1998. The split-plot was $20 \mathrm{~m}$ in length and $6.1 \mathrm{~m}$ in width. No-till system only was used for the 1999 corn production.

In all 3 years, corn test was conducted on different but adjacent fields. Corn hybrid "Pioneer 3820" was used each season. Potassium fertilizer was applied to the K-fertilized treatments just 1 day prior to corn planting at a rate of $100 \mathrm{~kg} \mathrm{Kha}^{-1}$ as muriate of potash $(0-0-50)$ in each corn season. Detailed corn management practices and corn responses to K placement and tillage systems were described in a previous publication (Vyn et al., 2002).

\subsection{Subsequent soybean season}

The identical experimental design and plot arrangement as the respective previous corn season were used for subsequent no-till soybean from 1998 to 2000. No $\mathrm{K}$ fertilizer was applied after corn or during the subsequent soybean season. Soybean was no-till planted in $19 \mathrm{~cm}$ wide rows in the same direction as the previous corn rows. Soybean cultivar Pioneer 9163 was planted in 1998 and 1999, and NK S08-80 was planted in 2000. Soybean was grown using the normal no-till management practices of the cooperating farm and region.

Composite soil samples were taken from each plot in spring prior to soybean planting at four depth intervals of $0-5,5-10,10-20$, and $20-30 \mathrm{~cm}$ for all three seasons. Ten probes of $2.5 \mathrm{~cm}$ diameter were collected for each sample; five cores were removed from areas at the center of old corn rows and five cores from the center of the interrow zones. After soil samples were air dried, ground to pass through a $2 \mathrm{~mm}$ sieve, and thoroughly mixed, $1.0 \mathrm{ml}$ soil was placed into a $50 \mathrm{ml}$ flask, and $10 \mathrm{ml}$ of $1 \mathrm{M}$ ammonium acetate $\left(\mathrm{NH}_{4} \mathrm{OAc}\right)$ buffered at $\mathrm{pH}$ of 7.0 was added into soil; the resulting solution was shaken for $15 \mathrm{~min}$ and filtered (Bates and Richards, 1993). Potassium in the filtrates was determined by atomic absorption spectroscopy. Soil $\mathrm{K}$ stratification coefficient (defined as the quotient of soil $\mathrm{K}$ concentrations in the $0-5 \mathrm{~cm}$ layer divided by $\mathrm{K}$ levels at the $10-20 \mathrm{~cm}$ depth) was used to describe the degree of vertical soil $\mathrm{K}$ stratification. When soil $\mathrm{K}$ stratification coefficient is greater than 1.5 , then soil $\mathrm{K}$ stratification is described as to be evident.

Leaf samples, consisting of 20 most recently full developed trifoliate leaves (petiole included) of soybean were randomly collected at initial flowering stage (R1) (Fehr et al., 1971) in mid-to-late July from each plot in each season for analyzing tissue $\mathrm{K}$ concentrations. Leaf samples were dried in a forced-air oven at $65^{\circ} \mathrm{C}$ for at least 3 days, and ground in a Wiley mill (Arthur K. Thomas Co., Philadelphia) to pass through a $1 \mathrm{~mm}$ screen. Potassium concentrations in leaf samples were analyzed using a dry ash method (Miller, 1998).

After soybean reached physiological maturity, seed yield was determined by harvesting a central strip of soybean $1 \mathrm{~m}$ wide with the whole plot length in each plot using a plot combine. Seed samples were taken at harvest for the determinations of seed composition. Seed moisture was determined using a Dickey-John GACII moisture meter (Dickey-John Corp., Auburn, IL). Seed yield was adjusted to moisture content of $130 \mathrm{~g} \mathrm{~kg}^{-1}$. Seed $\mathrm{K}$ concentrations were measured using the same procedures as those for leaf samples. The daily rainfall and air temperature were recorded each season on the experimental site.

In 1998 and 1999, the data of soil K levels before soybean planting, leaf $\mathrm{K}$ concentrations at initial flowering stage, and soybean yield was analyzed using general linear methods (glm) appropriate for 
a randomized complete block split-plot design. In 2000, all data were analyzed using glm for a randomized complete block design. Soybean responses to $\mathrm{K}$ placement was estimated using three contrasts which were: (1) applied vs. none applied (the mean response of the three $\mathrm{K}$ placements vs. where $\mathrm{K}$ was not applied); (2) deep band vs. surface broadcast; and (3) broadcast plus shallow band vs. surface broadcast. In the event of significant tillage by $\mathrm{K}$ placement interactions, corn response to $\mathrm{K}$ placement was assessed using these three contrasts within each tillage system.

\section{Results and discussion}

\subsection{Initial soil $K$ fertility before previous corn planting}

Initial soil-test $\mathrm{K}$ concentrations $(0-15 \mathrm{~cm}$ depth) were low $\left(<61 \mathrm{mg} \mathrm{l}^{-1}\right)$ for all three seasons according to the Ontario soil-test $\mathrm{K}$ interpretations (Table 1). Vertical soil $\mathrm{K}$ stratification was evident (K stratification coefficient is greater than 1.5) each season. Soil $\mathrm{K}$ concentrations in the surface $0-5 \mathrm{~cm}$ layer was approximately two times higher than $\mathrm{K}$ levels present at the $10-20 \mathrm{~cm}$ depth (Table 1). Soil-test K concentrations decreased sharply with soil depth; this phenomenon was consistent with previous studies in no-till systems (Ketchson, 1980; Vyn and Janovicek, 2001; Yin and Vyn, 2002a).

\subsection{Soil $K$ fertility before soybean planting}

In general, soil-test $\mathrm{K}$ concentrations and distribution at the $0-20 \mathrm{~cm}$ depth responded differently to residual spring $\mathrm{K}$ placement under different tillage systems (Table 2). In 1998, soil K concentrations were significantly increased by $\mathrm{K}$ applications in the $0-5$ and $5-10 \mathrm{~cm}$ layers in no-till and zone-till compared to no K (Table 2); but no significant increases were observed after mulch-till. Deep banding caused greater increases in soil $\mathrm{K}$ at the $5-10$ and $10-20 \mathrm{~cm}$ depth intervals than surface broadcast in no-till. In the 1999 season, similar tendencies as the 1998 season were observed. Soil K concentrations were significantly increased by $\mathrm{K}$ applications at $0-5,5-10$, and $10-20 \mathrm{~cm}$ depth intervals in no-till, and in the $0-5$ and $5-10 \mathrm{~cm}$ layers under zone-till compared to zero K (Table 2). Deep banding had greater soil K concentrations in 5-10 cm layer than surface broadcast in no-till. The 1998 and 1999 results indicated that deep banding of $\mathrm{K}$ could markedly reduce soil $\mathrm{K}$ stratification relative to surface broadcast under no-till. In 2000, K applications significantly increased soil $\mathrm{K}$ concentrations in $0-5,5-10$, and $10-20 \mathrm{~cm}$ layers in no-till; no significant differences were observed between deep banding and surface broadcasting (Table 2).

The positive residual effects of $\mathrm{K}$ fertilizer application on soil $\mathrm{K}$ with no-till and zone-till treatments have also been observed on medium and high-testing $\mathrm{K}$ soils (Yin and Vyn, 2002b). However, an interesting aspect of the current study is that soil-test $\mathrm{K}$ did not respond positively to $\mathrm{K}$ application in mulch-till. The differential responses of soil $\mathrm{K}$ among tillage systems may be attributed, in part, to somewhat higher soil $\mathrm{K}$ concentrations in the zero $\mathrm{K}$ control under mulch tillage than those in no-till and zone-till. Corn yield was not improved by $\mathrm{K}$ fertilization in the mulch-till system on this soil either (Vyn et al., 2002).

\subsection{Leaf $K$ concentrations at initial flowering stage}

Potassium fertilizer consistently increased soybean leaf $\mathrm{K}$ concentrations after no-till corn for all 3 years on this low K soil (Table 3). Spring-applied K significantly increased leaf $\mathrm{K}$ concentrations after mulch-till corn in 1998, but not in 1999 (Table 3). In all three seasons, there was no leaf $\mathrm{K}$ benefit to subsequent no-till soybean associated with deep-banded $\mathrm{K}$, or broadcast plus shallow-banded $\mathrm{K}$, relative to surface broadcast $\mathrm{K}$ for prior corn in any tillage system. The latter suggests that there was no benefit in departing from the common practice of surface $\mathrm{K}$ application to corn under no-till, zone-till, or mulch-till systems on these low K fields.

The consistent leaf $\mathrm{K}$ responses to $\mathrm{K}$ applications, plus lower leaf $\mathrm{K}$ concentrations from the no K control in the no-till system, suggest that soybean plant K uptake was impaired under no-till compared to zone-till and mulch-till. The improvements in leaf $\mathrm{K}$ nutrition associated with zone-till and mulch-till may be due to enhanced soil $\mathrm{K}$ availability to soybean, or increased soybean root K uptake capacity, or both. 
Table 2

Residual effects of spring K placement in previous-year corn on soil-test K concentrations $(0-20 \mathrm{~cm})$ before soybean planting in 1998 , 1999, and 2000

\begin{tabular}{|c|c|c|c|c|c|c|c|}
\hline \multirow{2}{*}{$\begin{array}{l}\text { Soil depth }(\mathrm{cm}) \\
\mathrm{K} \text { placement for corn }\end{array}$} & \multicolumn{3}{|c|}{ 1998, tillage for corn in 1997} & \multicolumn{3}{|c|}{ 1999, tillage for corn in 1998} & \multirow{2}{*}{$\begin{array}{l}2000, \text { tillage for } \\
\text { corn in } 1999 \\
\text { No-till }\left(\mathrm{mg}^{-1}\right)\end{array}$} \\
\hline & $\begin{array}{l}\text { No-till } \\
\left(\mathrm{mg}^{-1}\right)\end{array}$ & $\begin{array}{l}\text { Zone-till } \\
\left(\mathrm{mg}^{-1}\right)\end{array}$ & $\begin{array}{l}\text { Mulch-till } \\
\left(\mathrm{mg} \mathrm{1}^{-1}\right)\end{array}$ & $\begin{array}{l}\text { No-till } \\
\left(\mathrm{mg} \mathrm{1}^{-1}\right)\end{array}$ & $\begin{array}{l}\text { Zone-till } \\
\left(\mathrm{mg}^{-1}\right)\end{array}$ & $\begin{array}{l}\text { Mulch-till } \\
\left(\mathrm{mg}^{-1}\right)\end{array}$ & \\
\hline \multicolumn{8}{|l|}{$0-5$} \\
\hline Deep band & 141 & 126 & 108 & 82 & 114 & 90 & 103 \\
\hline Surface broadcast & 131 & 142 & 146 & 101 & 87 & 100 & 111 \\
\hline Broadcast + shallow band & 142 & 145 & 132 & 92 & 85 & 106 & 113 \\
\hline No $\mathrm{K}$ & 98 & 109 & 114 & 61 & 55 & 86 & 85 \\
\hline Contrasts: applied vs. no K & $* *$ & * & $\mathrm{ns}^{\mathrm{a}}$ & $*$ & $* *$ & ns & $*$ \\
\hline Deep band vs. surface broadcast & ns & ns & * & ns & ns & ns & ns \\
\hline $\begin{array}{c}\text { Broadcast }+ \text { shallow band } \\
\text { vs. surface broadcast }\end{array}$ & ns & ns & ns & ns & ns & ns & ns \\
\hline \multicolumn{8}{|l|}{$5-10$} \\
\hline Deep band & 91 & 77 & 68 & 48 & 39 & 44 & 64 \\
\hline Surface broadcast & 62 & 74 & 78 & 38 & 41 & 38 & 64 \\
\hline Broadcast + shallow band & 73 & 71 & 64 & 41 & 37 & 37 & 52 \\
\hline No $\mathrm{K}$ & 58 & 53 & 64 & 31 & 29 & 39 & 44 \\
\hline Contrasts: applied vs. no $\mathrm{K}$ & $* *$ & $* * *$ & ns & $* *$ & $* *$ & ns & * \\
\hline Deep band vs. surface broadcast & $* * *$ & ns & $\mathrm{ns}$ & $*$ & ns & ns & $\mathrm{ns}$ \\
\hline $\begin{array}{c}\text { Broadcast }+ \text { shallow band } \\
\text { vs. surface broadcast }\end{array}$ & ns & ns & $*$ & ns & ns & ns & ns \\
\hline \multicolumn{8}{|l|}{$10-20$} \\
\hline Deep band & 64 & 53 & 55 & 32 & 32 & 34 & 43 \\
\hline Surface broadcast & 43 & 45 & 48 & 34 & 29 & 30 & 42 \\
\hline Broadcast + shallow band & 47 & 47 & 47 & 31 & 28 & 31 & 34 \\
\hline No $\mathrm{K}$ & 43 & 39 & 49 & 27 & 27 & 31 & 33 \\
\hline Contrasts: applied vs. no K & ns & ns & ns & $*$ & ns & ns & $*$ \\
\hline Deep band vs. surface broadcast & $* *$ & ns & ns & ns & ns & ns & $\mathrm{ns}$ \\
\hline $\begin{array}{c}\text { Broadcast }+ \text { shallow band } \\
\text { vs. surface broadcast }\end{array}$ & ns & ns & ns & ns & ns & ns & ns \\
\hline
\end{tabular}

${ }^{a}$ Non-significant.

* Indicates the contrast is statistically significant at $P=0.05$.

** Indicates the contrast is statistically significant at $P=0.01$.

*** Indicates the contrast is statistically significant at $P=0.001$.

Leaf $\mathrm{K}$ concentrations in the no K plots in 1998 and 1999 were lower than $17.1 \mathrm{~g} \mathrm{~kg}^{-1}$, the lower limit of adequate $\mathrm{K}$ range in trifoliate leaves recommended for soybean (Small and Ohlrogge, 1973). However, leaf $\mathrm{K}$ concentrations were much greater than $17.1 \mathrm{~g} \mathrm{~kg}^{-1}$ in all treatments (including no $\mathrm{K}$ ) in 2000. If the mid-season leaf $\mathrm{K}$ concentrations were indicative, and all other soil and environmental factors were favorable for seed production, significant yield responses to $\mathrm{K}$ applications would have been expected in 1998 and 1999, but not in 2000. Leaf K concentrations from all $\mathrm{K}$-fertilized treatments were above the recommended adequate range in both 1998 and 2000, but significantly below the sufficiency range in 1999. This sug- gested that the biannual application of $100 \mathrm{~kg} \mathrm{~K} \mathrm{ha}^{-1}$ to previous corn was insufficient for subsequent no-till soybean to consistently reach optimum yield despite the improvement in leaf $\mathrm{K}$ nutrition relative to the zero $\mathrm{K}$ control.

Leaf K concentrations were much lower in 1999 than in 1998 and 2000 due, in part, to the lower initial soil K levels before corn planting in 1999 (Table 1). Much higher leaf $\mathrm{K}$ concentrations in 2000 were probably because the rainfall in June 2000 was more than double (data not shown) that received in 1998 and 1999, and soil K availability and plant $\mathrm{K}$ uptake were enhanced by higher soil moisture. 
Table 3

Residual effects of spring K placement for previous-year corn on leaf K concentrations and yield of soybean from 1998 to 2000

\begin{tabular}{|c|c|c|c|c|c|c|}
\hline \multirow{3}{*}{$\begin{array}{l}\text { Year } \\
\mathrm{K} \text { placement for corn }\end{array}$} & \multicolumn{6}{|c|}{ Tillage for corn } \\
\hline & \multicolumn{3}{|l|}{ Leaf $\mathrm{K}$} & \multicolumn{3}{|l|}{ Yield } \\
\hline & $\begin{array}{l}\text { No-till } \\
\left(\mathrm{g} \mathrm{kg}^{-1}\right)\end{array}$ & $\begin{array}{l}\text { Zone-till } \\
\left(\mathrm{g} \mathrm{kg}^{-1}\right)\end{array}$ & $\begin{array}{l}\text { Mulch-till } \\
\left(\mathrm{g} \mathrm{kg}^{-1}\right)\end{array}$ & $\begin{array}{l}\text { No-till } \\
\left(\mathrm{Mg} \mathrm{ha}^{-1}\right)\end{array}$ & $\begin{array}{l}\text { Zone-till } \\
\left(\mathrm{Mg} \mathrm{ha}^{-1}\right)\end{array}$ & $\begin{array}{l}\text { Mulch-till } \\
\left(\mathrm{Mg} \mathrm{ha}^{-1}\right)\end{array}$ \\
\hline \multicolumn{7}{|l|}{1998} \\
\hline Deep band & 19.1 & 17.5 & 18.7 & 2.11 & 1.93 & 2.11 \\
\hline Surface broadcast & 20.3 & 18.8 & 20.3 & 2.12 & 1.87 & 2.11 \\
\hline Broadcast + shallow band & 19.1 & 18.5 & 19.7 & 2.01 & 2.07 & 2.31 \\
\hline No $\mathrm{K}$ & 14.0 & 16.7 & 16.5 & 2.03 & 1.98 & 2.04 \\
\hline Contrasts: applied vs. no $\mathrm{K}$ & $* * *$ & $\mathrm{~ns}^{\mathrm{a}}$ & $* * *$ & $\mathrm{~ns}$ & ns & ns \\
\hline Deep band vs. surface broadcast & ns & ns & ns & $\mathrm{ns}$ & ns & ns \\
\hline $\begin{array}{c}\text { Broadcast }+ \text { shallow band } \\
\text { vs. surface broadcast }\end{array}$ & ns & ns & ns & ns & ns & ns \\
\hline \multicolumn{7}{|l|}{1999} \\
\hline Deep band & 14.1 & 15.1 & 14.1 & 2.84 & 2.95 & 2.93 \\
\hline Surface broadcast & 14.9 & 14.4 & 12.8 & 3.07 & 3.21 & 2.92 \\
\hline Broadcast + shallow band & 13.7 & 13.5 & 13.4 & 3.07 & 3.23 & 2.85 \\
\hline No $\mathrm{K}$ & 10.6 & 10.1 & 12.3 & 2.91 & 2.81 & 3.02 \\
\hline Contrasts: applied vs. no K & $* * *$ & $* * *$ & ns & ns & * & ns \\
\hline Deep band vs. surface broadcast & ns & ns & ns & $\mathrm{ns}$ & ns & ns \\
\hline $\begin{array}{c}\text { Broadcast }+ \text { shallow band } \\
\text { vs. surface broadcast }\end{array}$ & ns & ns & ns & ns & ns & ns \\
\hline \multicolumn{7}{|l|}{2000} \\
\hline Deep band & 25.0 & & & 3.19 & & \\
\hline Surface broadcast & 25.9 & & & 3.09 & & \\
\hline Broadcast + shallow band & 25.7 & & & 3.08 & & \\
\hline No $\mathrm{K}$ & 22.0 & & & 3.02 & & \\
\hline Contrasts: applied vs. no K & $* * *$ & & & ns & & \\
\hline Deep band vs. surface broadcast & ns & & & ns & & \\
\hline $\begin{array}{l}\text { Broadcast }+ \text { shallow band } \\
\text { vs. surface broadcast }\end{array}$ & ns & & & ns & & \\
\hline
\end{tabular}

a Non-significant.

* Indicates the contrast is statistically significant at $P=0.05$.

*** Indicates the contrast is statistically significant at $P=0.001$.

\subsection{Seed yield}

Seed yield generally did not benefit from K fertilizer applications to the preceding corn (Table 3) despite the positive influence of $\mathrm{K}$ applications on soil-test $\mathrm{K}$ and son leaf K concentrations. In 1998, seed yield was low in all treatments, with an average of approximately $2.1 \mathrm{Mg} \mathrm{ha}^{-1}$. Low overall soybean yield in 1998 likely resulted from extremely dry weather conditions late in the season. The rainfall from July to September in 1998 was only $67 \%$ of the 30 -year average $(266 \mathrm{~mm})$ during this period. In the 1999 season, significant yield increases of $11.4 \%\left(0.32 \mathrm{Mg} \mathrm{ha}^{-1}\right)$ were observed with $\mathrm{K}$ applications compared to no $\mathrm{K}$ in zone-till. The latter yield increase was expected because the initial soil $\mathrm{K}$ levels were very low, mid-season leaf $\mathrm{K}$ concentrations from the no $\mathrm{K}$ treatment was $7.0 \mathrm{~g} \mathrm{~kg}^{-1}$ lower than the accepted lower limit $\left(17.1 \mathrm{~g} \mathrm{~kg}^{-1}\right)$ of adequate leaf $\mathrm{K}$ concentrations, leaf $\mathrm{K}$ concentrations were $3.4-5.0 \mathrm{~g} \mathrm{~kg}^{-1}$ higher in the K-fertilized plots than in the no $\mathrm{K}$ control, and rainfall amounts were near normal in this season. In 2000, no significant yield increases were observed with $\mathrm{K}$ applications although the initial soil $\mathrm{K}$ levels were low and mid-season leaf $\mathrm{K}$ concentrations were much higher after K applications, relative to no K. Nevertheless, soil K availability was greatly improved in 2000 as a result of the very high precipitation amounts in the growing season. 
Furthermore, mid-season leaf $\mathrm{K}$ concentrations from the no $\mathrm{K}$ plots averaged $22.0 \mathrm{~g} \mathrm{~kg}^{-1}$.

Seed yield responses to prior $\mathrm{K}$ fertilizer applications appeared to be dependent on growing season rainfall. Both extended dry or extended wet weather conditions decreased $\mathrm{K}$ fertilization effects on subsequent soybean yield. Even on a low K soil, residual K fertilizer had greater impacts on leaf $\mathrm{K}$ nutrition than on the final seed yield of subsequent soybean. The adoption of mulch-till for prior corn on long-term no-till fields seemed to improve soybean $\mathrm{K}$ nutrition, and thus reduced soybean yield response to residual $\mathrm{K}$ fertilizer.

Seed yields were no higher after deep banding relative to broadcasting, just as mid-season leaf $\mathrm{K}$ concentrations were no higher with deep banding of $\mathrm{K}$ fertilizer. This may be due to the fact that the soybean row width used in this study was $19 \mathrm{~cm}$; so most soybean rows were not in proximity to residual $\mathrm{K}$ fertilizer bands spaced $76 \mathrm{~cm}$ apart. In another investigation involving no-till soybean response to direct $\mathrm{K}$ fertilization, conducted simultaneously on the same soil, deep banding was only superior to broadcasting when soybean rows were positioned in close proximity to the fertilizer bands (Yin and Vyn, 2003). The results of previous studies (Hudak et al., 1989; Hairston et al., 1990) also indirectly reflected the influence of soybean row position relative to $\mathrm{K}$ fertilizer bands on the relative effectiveness of deep-banded $\mathrm{K}$.

\section{Conclusions}

No-till soybean response to residual $\mathrm{K}$ fertilizer management for corn varied with the tillage systems utilized in corn. Incremental gains in soybean leaf $\mathrm{K}$ responses were consistent after $\mathrm{K}$ application for no-till corn, but less consistent after $\mathrm{K}$ application to zone-till and mulch-till corn. Potassium applications by deep band, broadcast plus shallow band, and surface broadcast methods for corn were equally effective in increasing soybean leaf $\mathrm{K}$ concentrations on these low soil K fields. Soybean yield increases following $\mathrm{K}$ application to prior corn was observed in only 1 out of 3 years even though soil $\mathrm{K}$ levels before soybean planting, and mid-season soybean leaf $\mathrm{K}$ concentrations, were significantly increased by residual $\mathrm{K}$ fertilizer.
Surface broadcasting of K fertilizer before corn was as effective for subsequent narrow-row soybean as deep banding of $\mathrm{K}$ fertilizer before corn; the simpler broadcast application strategy may thus be the preferred biannual $\mathrm{K}$ management practice for soybean following corn on similar long-term no-till fields with low soil $\mathrm{K}$ concentrations. Occasional mulch tillage seemed to be an appropriate alternative to continuous no-till as it increased soil $\mathrm{K}$ availability and leaf $\mathrm{K}$ nutrition for both corn and subsequent no-till soybean regardless of $\mathrm{K}$ application methods for prior corn. Although the residual $\mathrm{K}$ availability benefits associated with $\mathrm{K}$ application and tillage disturbance in the corn year seemed to persist into the second year of a corn-soybean rotation, the application of $100 \mathrm{~kg} \mathrm{ha}^{-1}$ $\mathrm{K}$ fertilizer to conservation-till corn was not always sufficient to ensure adequate leaf $\mathrm{K}$ nutrition on this low $\mathrm{K}$ soil.

\section{Acknowledgements}

Research was supported by Purdue Research Foundation, Agricultural Adaptation Council of Canada, Ontario Soybean Growers' Marketing Board, and Ontario Ministry of Agriculture, Food, and Rural Affairs.

\section{References}

Barber, S.A., 1971. Effect of tillage practice on corn (Zea mays L.) root distribution and root morphology. Agron. J. 63, 724-726.

Bates, T.E., Richards, J.E., 1993. Available potassium. In: Carter, M.R. (Ed.), Soil Sampling and Methods of Analysis. Lewis Publishers, Boca Raton, FL, pp. 59-64.

Borges, R., Mallarino, A.P., 2000. Grain yield, early growth, and nutrient uptake of no-till soybean as affected by phosphorus and potassium placement. Agron. J. 92, 380-388.

Buah, S.S.J., Polito, T.A., Killorn, R., 2000. No-tillage soybean response to banded and broadcast and direct and residual fertilizer phosphorus and potassium applications. Agron. J. 92, 657-662.

Chan, K.Y., Roberts, W.P., Heenan, D.P., 1992. Organic carbon and associated soil properties of a red earth after 10 years of rotation under different stubble and tillage practices. Aust. J. Soil Res. 30, 71-83.

Cruse, R.M., Yakle, G.A., Colvin, T.C., Timmons, D.R., Mussleman, A.L., 1983. Tillage effects on corn and soybean production in farmer-managed, university-monitored field plots. J. Soil Water Conserv. 38, 512-514. 
Fehr, W.R., Caviness, C.E., Burmood, D.T., Pennington, J.S., 1971. Stage of development descriptions for soybeans, Glycine max (L.) Merrill. Crop Sci. 11, 929-931.

Fink, R.J., Wesley, D., 1974. Corn yield as affected by fertilization and tillage systems. Agron. J. 66, 70-71.

Fortin, M.C., 1993. Soil temperature, soil water, and no-till corn development following in-row residue removal. Agron. J. 85, 571-576.

Hairston, J.E., Jones, W.F., McConnaughey, P.K., Marshall, L.K., Gill, K.B., 1990. Tillage and fertilizer management effects on soybean growth and yield on three Mississippi soils. J. Prod. Agric. 3, 317-323.

Holanda, F.S.R., Mengel, D.B., Paula, M.B., Carvado, J.G., Bertoni, J.C., 1998. Influence of crop rotations and tillage systems on phosphorus and potassium stratification and root distribution in soil profile. Commun. Soil Sci. Plant Anal. 29, 2383-2394.

Hudak, C., Stehouwer, R., Johnson, J., 1989. An evaluation of K rate, placement and tillage systems for soybeans. J. Fert. Issues 6, 25-31.

Karathanasis, A.D., Wells, K.L., 1989. A comparison of mineral weathering trends between two management systems on a catena of loess-derived soils. Soil Sci. Soc. Am. J. 53, 582-588.

Ketchson, J.W., 1980. Effect of tillage on fertilizer requirements for corn on a silt loam soil. Agron. J. 72, 540-542.

Miller, R.O., 1998. High temperature oxidation: dry ashing. In: Kalra, Y. (Ed.), Handbook of Reference Methods for Plant Analysis. CRC Press, Boca Raton, FL, pp. 53-57.

Ontario Ministry of Agriculture, Food and Rural Affairs (OMFARA), 1997. Field crop recommendations 1997-1998. Public. 296. OMFARA, Guelph, ON, Canada.

Opoku, G., Vyn, T.J., Swanton, C.J., 1997. Modified no-till systems for corn following wheat on clay soils. Agron. J. 89, 549556.

Rehm, G.W., 1995. Impact of banded potassium for corn and soybean production in a ridge-till planting system. Commun. Soil Sci. Plant Anal. 26, 2725-2738.
Schoneau, J.J., Karamanos, R.E., 1993. Sodium bicarbonateextractable P, K, and N. In: Carter, M.R. (Ed.), Soil Sampling and Methods of Analysis. Lewis Publishers, Boca Raton, FL, pp. $51-58$.

Simard, R.R., 1993. Ammonium acetate-extractable elements. In: Carter, M.R. (Ed.), Soil Sampling and Methods of Analysis. Lewis Publishers, Boca Raton, FL, pp. 39-42.

Small Jr., H.G., Ohlrogge, A.J., 1973. Plant analysis as an aid in fertilizing soybeans and peanuts. In: Walsh, L.M., Beaton, J.D. (Eds.), Soil Testing and Plant Analysis, Revised edition. SSSA, Madison, WI, pp. 315-327.

Sprague, A.D., Triplett, G.B., 1986. No-tillage and Surface Tillage Agriculture, the Tillage Revolution. Wiley, New York.

Vasilas, B.L., Esgar, R.W., Walker, W.M., Beck, R.H., Mainz, M.J., 1988. Soybean response to potassium fertility under four tillage systems. Agron. J. 80, 5-8.

Vyn, T.J., Janovicek, K.J., 2001. Potassium placement and tillage system effects on corn response following long-term no-till. Agron. J. 93, 487-495.

Vyn, T.J., Raimbault, B.A., 1992. Evaluation of strip tillage systems for corn production in Ontario. Soil Till. Res. 23, 161176.

Vyn, T.J., Raimbault, B.A., 1993. Long-term effect of five tillage systems on corn response and soil structure. Agron. J. 85, 1074-1079.

Vyn, T.J., Galic, D.M., Janovicek, K.J., 2002. Conservation-till corn response to placement of spring applied $\mathrm{K}$ in Ontario. Soil Till. Res. 67, 159-169.

Yin, X.H., Vyn, T.J., 2002a. Soybean responses to potassium placement and tillage alternatives following no-till. Agron. J. 94, 1367-1374.

Yin, X.H., Vyn, T.J., 2002b. Residual effects of potassium placement and tillage systems for corn on subsequent no-till soybean. Agron. J. 94, 1112-1119.

Yin, X.H., Vyn, T.J., 2003. Potassium placement effects on yield and seed composition of no-till soybean seeded in alternate row widths. Agron. J. 95, 126-132. 